\title{
Bacterial Structure and Community-Level Physiological Profiles in Water From Vistula River, Lubelskie, Poland
}

\author{
Karolina Furtak 1,*, Jarosław Grządziel 1, Anna Gałązka ${ }^{1}$, Jacek Niedźwiecki ${ }^{2}$ \\ 1 Department of Agricultural Microbiology, Institute of Soil Science and Plant Cultivation - State Research \\ Institute, Czartoryskich 8, 24-100 Puławy, Poland; jaroslaw.grzadziel@gmail.com (J.G.); \\ agalazka@iung.pulawy.pl (A.G.) \\ 2 Department of Soil Science Erosion and Land Protection, Institute of Soil Science and Plant Cultivation - \\ State Research Institute, Czartoryskich 8, 24-100 Puławy, Poland; jacekn@iung.pulawy.pl \\ * Correspondence: kfurtak@iung.pulawy.pl; Tel.: +814786961
}

\begin{abstract}
The Vistula River is Poland's longest river, and its section called the Lesser Poland Gorge of the Vistula (Polish: Małopolski Przełom Wisły) belongs to two Natura 2000 Areas. The waters of the Vistula River periodically flood neighbouring areas during winter or summer floods. In this study we decided to determine the composition of the bacterial community and its metabolic potential in Vistula River water. In order to analyse the structure of bacterial communities, the next generation V3/V4 16S rDNA region sequencing (NGS) using Miseq (Ilumina) and the communitylevel physiological profiles (CLPP) method using the Biolog ${ }^{\circledR}$ EcoPlate $^{\mathrm{TM}}$ system were applied. A total of 413 operational taxonomic units (OTU) were obtained, of which 377 could not be classified at genera level. Among those identified, Arenimonas (2.13\%), Brevundimonas (1.44\%) and Flavobacterium $(1.05 \%)$ predominated. The most intensively degraded group of substrates were carbohydrates (30.93\%) and the least amines and amides (6.44\%). The NGS analysis did not indicate a sanitary risk to humans. A large number of unclassified bacteria indicate a still low level of knowledge and limitations concerning the world of bacteria.
\end{abstract}

Keywords: bacteria; CLPP; EcoPlate; NGS; Vistula River; water

\section{Introduction}

The Vistula River is Poland's longest river, and its section called the Lesser Poland Gorge of the Vistula (Polish: Małopolski Przełom Wisły) belongs to two Natura 2000 Areas [1]. The waters of the Vistula River periodically flood neighbouring areas during winter or summer floods [2]. Among studies on the microbiome of river waters, sanitary analyses to control drinking water dominate [3]. The most frequently determined bacteria are Escherichia coli and Enterobacter, Citrobacter and Klebsiella.

The aim of this study was to determine the composition of the bacterial community and its metabolic potential in Vistula River water.

\section{Materials and Methods}

\subsection{Water from the Vistula River}

Water was taken from the Vistula River from Janowiec, Lubelskie Voivodeship $\left(51^{\circ} 19^{\prime} 06.8^{\prime \prime} \mathrm{N}\right.$ $21^{\circ}$ and $54^{\prime} 53.5^{\prime \prime} \mathrm{E}$ ) in August 2018. The water was taken from the river at a distance of about $27 \mathrm{~m}$ from the riverbank into three sterile 50-litre containers (total $\sim 150 \mathrm{~L}$ ). Selected water parameters are presented in Table 1.

Table 1. Selected chemical parameters and trace elements contents $(\mathrm{mg} / \mathrm{L})$ in water.

$\mathrm{pH} \quad \mathrm{EC}$

Metals content $\left(\mathrm{mg} \mathrm{L}^{-1}\right)^{1}$ 


\begin{tabular}{|c|c|c|c|c|c|c|c|c|c|c|c|}
\hline & $\left(\mu S \mathrm{~cm}^{-1}\right)$ & $\mathbf{K}$ & $\mathrm{Ca}$ & Mg & $\mathrm{Na}$ & $\mathrm{Fe}$ & Mn & $\mathrm{Cu}$ & $\mathrm{Cd}$ & Al & $\mathbf{P b}$ \\
\hline $0-5$ & 270 & 4.567 & 49.395 & 10.760 & 60.97 & 0.035 & 0.035 & 0.002 & $<0.001$ & $<0.001$ & $<0.001$ \\
\hline 8.54 & 370 & \pm 0.257 & \pm 2.423 & \pm 0.547 & \pm 0.85 & \pm 0.001 & \pm 0.001 & \pm 0.000 & \pm 0.000 & \pm 0.000 & \pm 0.000 \\
\hline
\end{tabular}

${ }^{1}$ Values are the average of three replicates $(n=3)$; means \pm standard deviation (SD).

The water $\mathrm{pH}$ was slightly alkaline and was 8.54 and the electrical conductivity (EC) was $370 \mu \mathrm{S}$ $\mathrm{cm}^{-1}$ (Table 1).

\subsection{The colony PCR and next generation sequencing (NGS)}

The direct PCR, also known as colony PCR [4] was performed on water from Vistula. All details of the procedure are described in Furtak et al. (2020) [5]. The resulting product (about $1500 \mathrm{nt}$ ) was then used as a template for $\mathrm{V} 3-\mathrm{V} 4$ region sequencing.

The V3-V4 region of the $16 \mathrm{~S}$ rRNA gene was sequenced using $341 \mathrm{~F}$ and $785 \mathrm{R}$ primers [6] at Genomed S.A. (Warsaw, Poland), in $2 \mathrm{bp} \times 250$ bp paired-end technology using the Illumina MiSeq system.

The sequences obtained are available at the NCBI database under the bioproject accession number: PRJNA552453 (https://www.ncbi.nlm.nih.gov/bioproject/PRJNA552453/).

\subsection{The community-level physiological profiles (CLPP)}

The diversity of the metabolic potential of the bacterial community from water was determined using the Biolog EcoPlate ${ }^{\mathrm{TM}}$ (Biolog Inc., Hayward, CA, USA) system with 31 different carbon sources in three replicates.

The water was applied (without dilution) to the EcoPlate ${ }^{\mathrm{TM}}$ plate in a volume of $120 \mu \mathrm{l}$ to each well. EcoPlates ${ }^{\mathrm{TM}}$ were incubated at $25^{\circ} \mathrm{C}$ for $120 \mathrm{~h}$ in the OmniLog ${ }^{\circledR}$ ID System multiplate reader (Biolog Inc., Hayward, CA, USA). The intensity of the wells' colour development was determined spectrophotometrically at $\lambda=590 \mathrm{~nm}$ [7] at 24-intervals using a MicroStation ID (Biolog Inc., Hayward, CA, USA) plate reader.

Substrates from EcoPlate ${ }^{\mathrm{TM}}$ weere classificated into five biochemical groups: ; according to Weber and Legge (2009) [8].

\subsection{Data analysing}

Details of bioinformatic data processing are described in detail in Furtak et al. (2020) [5]. The analyses were performed using the DADA2 (1.12) package [9] in R software (3.6.0) [10].

On the basis of the data from Biolog EcoPlate ${ }^{\mathrm{TM}}$ (after $120 \mathrm{~h}$ of incubation), the average well colour development $(\mathrm{AWCD})$, richness $(R)$, Shannon diversity $\left(H^{\prime}\right)$ and evenness $(E)$ indices were calculated following Garland and Mills (1991) [11]. Heatmaps were generated on OmniLog units in R software (3.6.0) using the phyloseq package [12].

\section{Results}

\subsection{Structural diversity of the bacterial community}

A total of 413 operational taxonomic units (OTU) were obtained, of which 377 could not be classified at genera level (Table 2). Based on this data the calculated Shannon's biodiversity index was 4.94 .

Table 2. Selected diversity indices obtained for NGS results.

\begin{tabular}{|c|c|c|c|c|c|c|c|c|}
\hline \multicolumn{3}{|c|}{ Number of sequences } & \multirow{2}{*}{ Dominance (D) } & \multirow{2}{*}{ Simpson (1/D) } & \multirow{2}{*}{ Shannon $\left(\mathrm{H}^{\prime}\right)$} & \multirow{2}{*}{ Evenness (E) } & \multirow{2}{*}{ Chao-1 } & \multirow{2}{*}{ Fisher } \\
\hline All & Classified to genus & Unclassified & & & & & & \\
\hline 413 & 36 & 377 & 0.014 & 0.986 & 4.939 & 0.348 & 401 & 62.570 \\
\hline
\end{tabular}

In the water taken from the Vistula River 53 different bacterial families were identified, the most numerous of which were Planctomycetaceae (18.5\%) and Xanthomonadaceae (13.8\%). Among the identified classes of bacteria the most abundant were Betaproteobacteria (21.5\%). 
Of the sequensec present above $1 \%$ in the water, 23 were unclassified, including the dominant Unclassified_CL0182 (5.05\%), belonging to the family Plantomycetaceae (Figure 1). Among those identified, Arenimonas (2.13\%), Brevundimonas (1.44\%) and Flavobacterium (1.05\%) predominated.

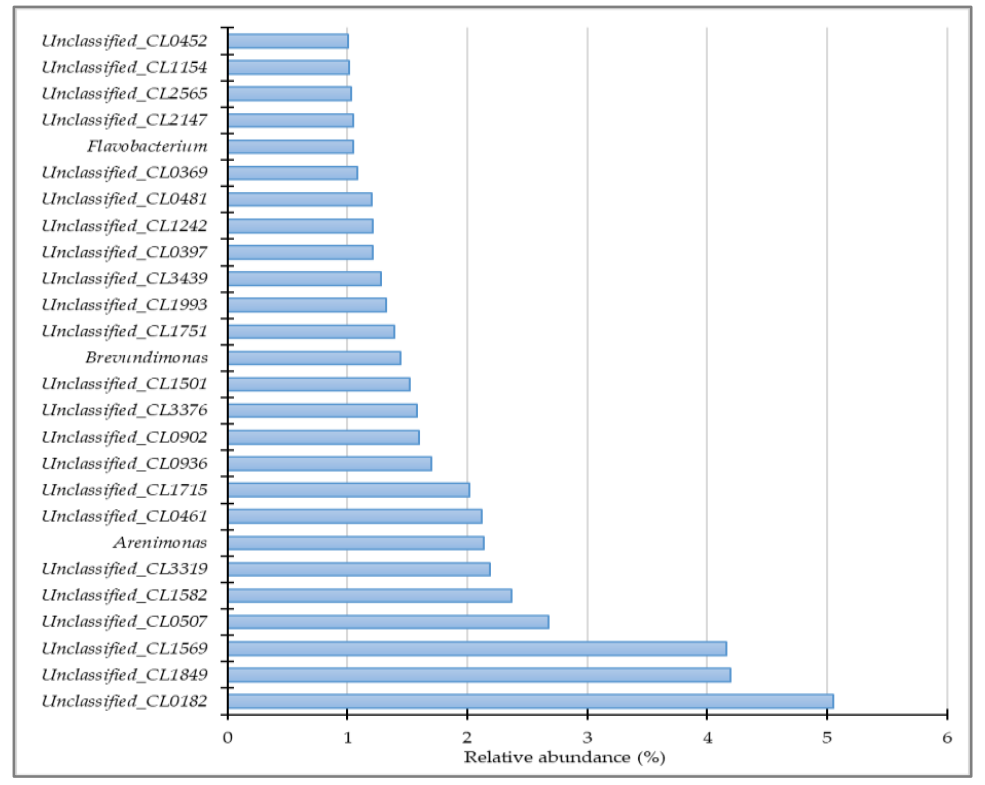

Figure 1. Sequences that occurred in more than $1 \%$ in water sample from Vistula River.

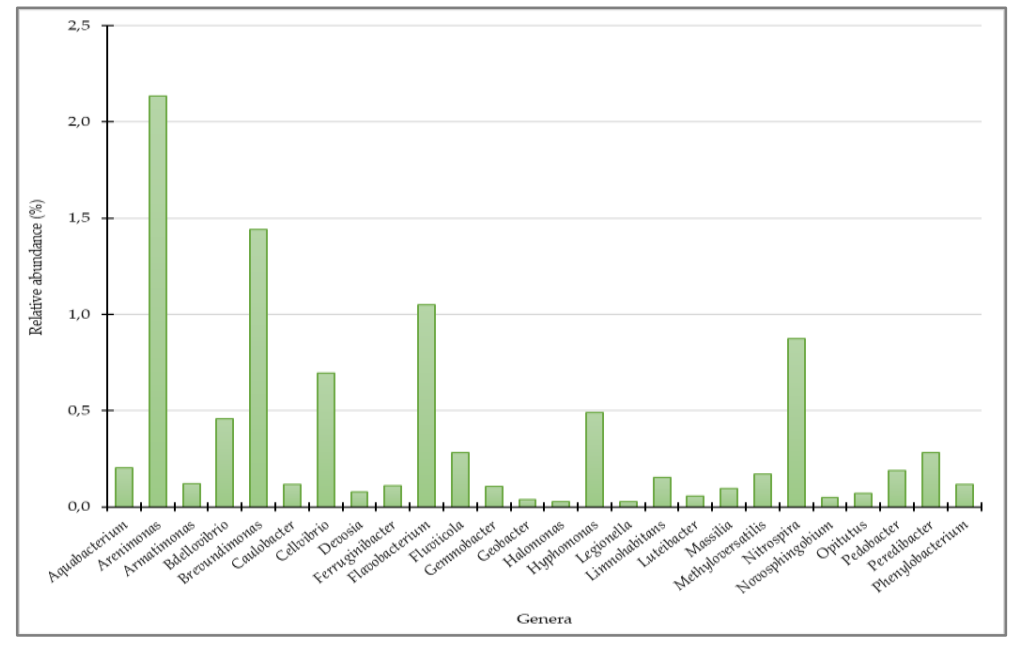

Figure 2. Relative abundance (\%) of classified at genera level bacterial sequences.

While searching for bacteria pathogenic to humans, few representatives of Legionella sp. (0.03\%) and Rickettsia sp. (0,03 \%). Additionally, the presence of bacteria from the genus Brevundimonas $(1.44 \%)$ and from the family Oxalobacteraceae $(0.09 \%)$ was detected, which may cause opportunistic infections. The results obtained are surprising, as it is commonly believed that river waters are contaminated with pathogenic microorganisms.

\subsection{Metabolic potential of the bacterial community}

The highest AWCD and Shannon's diversity index $\left(\mathrm{H}^{\prime}\right)$ was recorded after 120 hours of incubation of EcoPlate ${ }^{\mathrm{TM}}$ (Figure 3). 


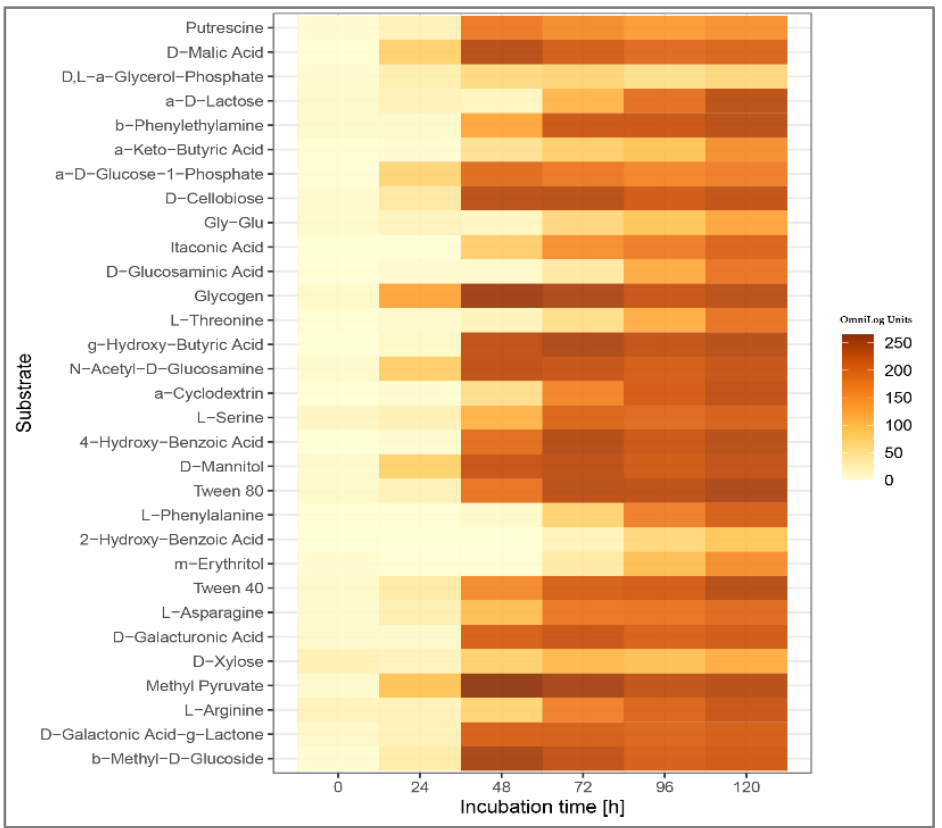

Figure 3. Heatmaps of EcoPlate ${ }^{\mathrm{TM}}$ substrate utilisation by bacterial community during incubation time.

Table 2. Indices obtained for EcoPlate ${ }^{\mathrm{TM}}$ results and utilization (\%) of group of substrates by bacterial community after $120 \mathrm{~h}$ incubation.

\begin{tabular}{cccccccc}
\hline & Indice & \multicolumn{5}{c}{ Utilization (\%) of 5 groups of substrates } \\
AWCD & $\begin{array}{c}\text { Shannon } \\
\left(\mathbf{H}^{\prime}\right)\end{array}$ & $\begin{array}{c}\text { Evenness } \\
(\mathrm{E})\end{array}$ & Carbohydrates & $\begin{array}{c}\text { Amines } \\
\text { \& amides }\end{array}$ & $\begin{array}{c}\text { Amino } \\
\text { acids }\end{array}$ & $\begin{array}{c}\text { Carboxylic } \\
\text { acids }\end{array}$ & Polymers \\
\hline 1.642 & 3.301 & 0.841 & 30.93 & 6.44 & 15.46 & 28.52 & 18.65 \\
\hline
\end{tabular}

The microorganisms present in the water most intensively decomposed carbohydrate group substrates (30.93\%) and the least intensively compounds classified as amines and amides $(6.44 \%)$ (Table 2).

The NGS analysis did not indicate a sanitary risk to humans. A large number of unclassified bacteria indicate a still low level of knowledge and limitations concerning the world of bacteria.

Acknowledgments: The research was conducted within the grant for young scientists in IUNG-PIB (MNiSW): Influence of summer floods on changes in structural and functional biodiversity of microbiomes of selected river muds (2018).

Conflicts of Interest: The authors declare no conflict of interest.

\section{References}

1. Natura 2000. Available online: http://natura2000.eea.europa.eu/ (accessed on 14 November 2020).

2. Cyberski, J.; Grześ, M.; Gutry-Korycka, M.; Nachlik, E.; Kundzewicz, Z.W. History of floods on the River Vistula, Hydrological Sciences Journal 2006, 51:5, 799-817.

3. Figureas, M.J.; Borrego, J.J.; Pike, E.B.; Robertson, W.; Ashbolt, N. Sanitary inspection and microbiological water quality. In Monitoring Bathing Waters - A Practical Guide to the Design and Implementation of Assessments and Monitoring Programmes; Bartram, J., Rees, G., Eds.; WHO, 2000.

4. Woodman, M.E.; Savage, C.R.; Amold, W.K.; Stevenson, B. Direct PCR of Intact Bacteria (Colony PCR). Curr. Protoc. Microbiol. 2016, 42, 1.

5. Furtak, K.; Grządziel, J.; Gałązka, A.; Niedźwiecki, J. Prevalence of unclassified bacteria in the soil bacterial community from floodplain meadows (fluvisols) under simulated flood conditions revealed by a metataxonomic approaches. Catena 2020, 188. 
6. Klindworth, A.; Pruesse, E.; Schweer, T.; Pepiles, J.; Quast, C.; Horn, M.; Glockner, F.O. Evaluation of general 16S ribosomal RNA gene PCR primers for classical and next-generation sequencing-based diversity studies. Nucleic Acids Res. 2013, 41(1), e1.

7. Insam, H.; Goberna, M. Use of Biolog ${ }^{\circledR}$ for the Community Level Physiological Profiling (CLPP) of environmental samples. In Molecular Microbial Ecology Manual. Kowalchuk, G.A., de Brujin, F.J., Head, I.M., Akkermans, A.D., van Elsas, J.D. (Eds.); Kluwer Academic Publishers: Dordrecht, Netherlands, 2004; pp. 853-860.

8. Weber, K.P.; Legge, R.L. One-dimensional metric for tracking bacterial community divergence using sole carbon source utilization patterns. J. Microbiol. Methods 2009, 79, 55-61.

9. Callahan, B.J.; McMuride, P.J.; Rosen, M.J.; Han, A.W.; Johnson, A.J.A.; Holmes, S.P. DADA2: Highresolution sample inference from Illumina amplicon data. Nature Methods 2016, 13, 581-583.

10. Team, R. C. R: A language and environment for statistical computing. 2016.

11. Garland, J.L.; Mills, A.L. Classification and characterization of heterotrophic microbial communities on the basis of patterns of community-level sole-carbon-source utilization. Appl. Environ. Microbiol. 1991, 57, 8, 2351-2359.

12. McMurdie, P. J.; Holmes, S. phyloseq: An R Package for Reproducible Interactive Analysis and Graphics of Microbiome Census Data. PLoS One 2013, 8, e61217.

(C) 2020 by the authors; licensee MDPI, Basel, Switzerland. This article is an open access article distributed under the terms and conditions of the Creative Commons by Attribution (CC-BY) license (http://creativecommons.org/licenses/by/4.0/). 